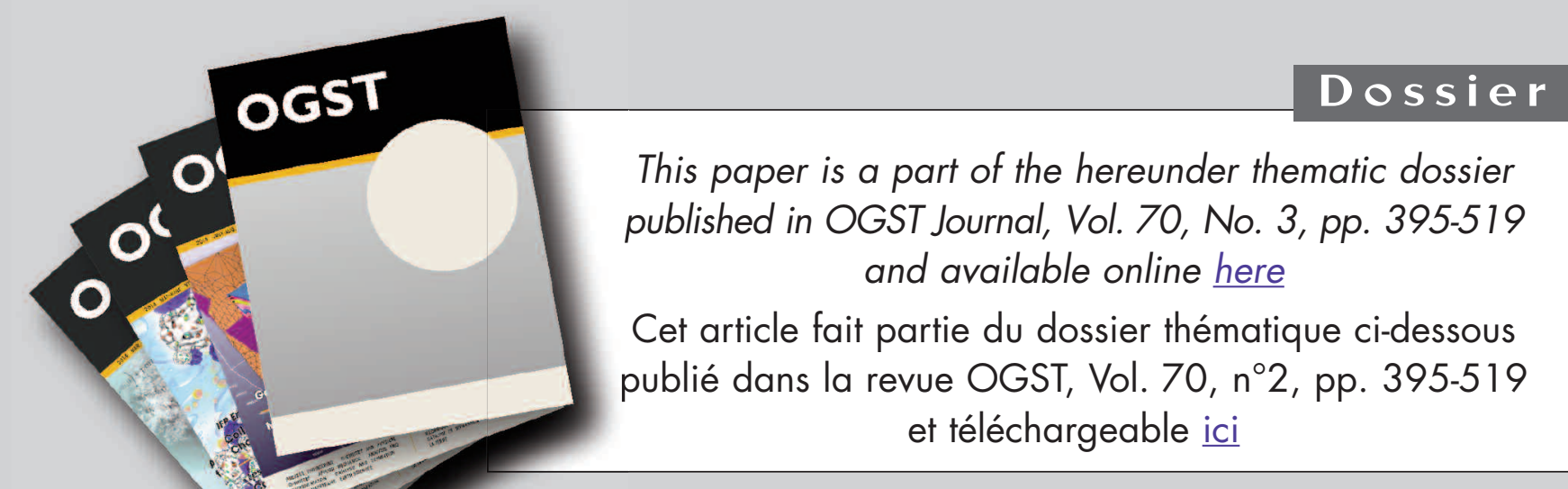

DOSSIER Edited by/Sous la direction de : V. Santos-Moreau

IFP Energies nouvelles International Conference / Les Rencontres Scientifiques d'IFP Energies nouvelles NEXTLAB 2014 - Advances in Innovative Experimental Methodology or Simulation Tools used to Create, Test, Control and Analyse Systems, Materials and Molecules

NEXTLAB 2014 - Innover dans le domaine de la méthodologie expérimentale et des outils de simulation pour créer, tester, contrôler et analyser des systèmes, matériaux et molécules

Oil \& Gas Science and Technology - Rev. IFP Energies nouvelles, Vol. 70 (2015), No. 3, pp. 395-519

Copyright (C) 2015, IFP Energies nouvelles

$395>$ Editorial - Towards the Laboratory of the Future for the Factory of the Future Éditorial - Vers le laboratoire du futur pour construire l'usine du futur V. Santos-Moreau, J.M. Newsam and J.-C. Charpentier

$405>$ Automatic and Systematic Atomistic Simulations in the MedeA ${ }^{\circledR}$ Software Environment: Application to EU-REACH

Simulations atomistiques automatiques et systématiques dans l'environnement logiciel de MedeA® : application à EU-REACH

$X$. Rozanska, P. Ungerer, B. Leblanc, P. Saxe and E. Wimmer

419 > Development of an Innovative XRD-DRIFTS Prototype Allowing Operando Characterizations during Fischer-Tropsch Synthesis over Cobalt-Based Catalysts under Representative Conditions

Développement d'un prototype DRX-DRIFTS innovant permettant des caractérisations operando de catalyseurs à base de cobalt pendant la synthèse de Fischer-Tropsch en conditions représentatives

J. Scalbert, I. Clémençon, C. Legens, F. Diehl, D. Decottignies and S. Maury

429 > Synchrotron X-ray Scattering as a Tool for Characterising Catalysts on Multiple Length Scales

La diffusion des rayons $X$ synchrotron : un outil pour la caractérisation des catalyseurs sur les multiples échelles de longueur

J.M. Hudspeth, K.O. Kvashnina, S.A.J. Kimber and E.P. Mitchell

437 > High Throughput Experimentation (HTE) Directed to the Discovery,

Characterization and Evaluation of Materials

Expérimentation à haut débit pour la découverte, la caractérisation et

l'évaluation des matériaux

J.M. Newsam

447 > The Use of Original Structure-Directing Agents for the Synthesis of EMC-1 Zeolite L'utilisation d'agents structuraux originaux pour la synthèse de zéolithe EMC-1

T.J. Daou, J. Dhainaut, A. Chappaz, N. Bats, B. Harbuzaru, H. Chaumeil, A. Defoin,

L. Rouleau and J. Patarin
455 > REALCAT: A new Platform to Bring Catalysis to the Lightspeed REALCAT : une nouvelle plate-forme pour mener la catalyse à la vitesse de la lumière

S. Paul, S. Heyte, B. Katryniok, C. Garcia-Sancho, P. Maireles-Torres and F. Dumeignil

$463>$ What are the Needs for Process Intensification? Quels besoins pour intensifi er un procédé ?

C. Gourdon, S. Elgue and L. Prat

$475>$ Revisiting the Side Crushing Test Using the Three-Point Bending Test for the Strength Measurement of Catalyst Supports

Test d'écrasement grain à grain revisité à l'aide du test de flexion trois points pour la mesure de la résistance des supports de catalyseurs D. Staub, S. Meille, V. Le Corre, J. Chevalier and L. Rouleau

487 > Refractometric Sensing of Heavy Oils in Fluorescent Core Microcapillaries La détection réfractométrique des huiles lourdes dans les microcapillaires à cœur fluorescents

V. Zamora, Z. Zhang and A. Meldrum

497 > Two-Phase Flow in Pipes: Numerical Improvements and Qualitative Analysis for a Refining Process

Écoulements diphasiques dans les conduites : améliorations numériques et analyse qualitative pour un procédé de raffinage

R.G.D. Teixeira, A.R. Secchi and E.C. Biscaia Jr

511 > Comparative TPR and TPD Studies of Cu and Ca Promotion on Fe-Zn- and Fe-Zn-Zr-Based Fischer-Tropsch Catalysts

Études comparatives par TPR et TPD de la promotion par Cu et Ca de I'activité de catalyseurs Fischer-Tropsch Fe-Zn et Fe-Zn-Zr 0.0 . James, B. Chowdhury and S. Maity 
NEXTLAB 2014 - Advances in Innovative Experimental Methodology or Simulation Tools used to Create, Test, Control and Analyse Systems, Materials and Molecules

NEXTLAB 2014 - Innover dans le domaine de la méthodologie expérimentale et des outils de simulation pour créer, tester, contrôler et analyser des systèmes, matériaux et molécules

\title{
The Use of Original Structure-Directing Agents for the Synthesis of EMC-1 Zeolite
}

\author{
T.J. Daou ${ }^{1 *}$, J. Dhainaut ${ }^{1,2}$, A. Chappaz ${ }^{1,3}$, N. Bats ${ }^{2}$, B. Harbuzaru², H. Chaumeil ${ }^{3}$, \\ A. Defoin ${ }^{3}$, L. Rouleau ${ }^{2}$ and J. Patarin ${ }^{1}$ \\ ${ }^{1}$ Université de Haute Alsace (UHA), CNRS, Équipe Matériaux à Porosité Contrôlée (MPC), Institut de Science des Matériaux de Mulhouse (IS2M) \\ UMR 7361, ENSCMu, 68093 Mulhouse Cedex - France \\ 2 IFP Energies nouvelles, Rond-point de l'échangeur de Salaize, BP 3, 69360 Solaize - France \\ ${ }^{3}$ Université de Haute Alsace (UHA), Laboratoire de Chimie Organique et Bioorganique (COB), EA 4566, \\ ENSCMu, 68093 Mulhouse Cedex - France \\ e-mail: jean.daou@uha.fr - jeremy.dhainaut@gmail.com - alban.chappaz@ifpen.fr - nicolas.bats@ifpen.fr - bogdan.harbuzaru@ifpen.fr \\ helene.chaumei@@uha.fr - albert.defoin@uha.fr - loic.rouleau@ifpen.fr - joel.patarin@uha.fr \\ * Corresponding author
}

\begin{abstract}
By using a steric approach, it is possible to design templates matching closely with an inorganic framework. Herein, the design, synthesis and successful application of several di(azacrown ether) templates to direct the formation of EMC-1 zeolite (FAU-type) are reported. Following a high throughput experiment design, the synthesis gel composition was optimized to obtain well-crystallized materials. Taking into account their respective crystallization rates, their textural and morphological properties were comparable to their counterparts, typically structured by 15-crown-5 ether.
\end{abstract}

Résumé - L'utilisation d'agents structuraux originaux pour la synthèse de zéolithe EMC-1 En utilisant une approche "stérique », il est possible de concevoir des agents structurants qui s'adaptent bien à la porosité de la charpente minérale. Ici, la conception, la synthèse et l'application réussie de plusieurs agents structurants de type di(aza-éther-couronne) pour diriger la formation de zéolithe EMC-1 de type FAU sont reportés. Suite à des synthèses à haut-débit, la composition du gel de synthèse a été optimisée pour obtenir des matériaux bien cristallisés. Compte tenu de leurs taux de cristallisation respectifs, leurs propriétés texturales et morphologiques sont comparables à leurs homologues, généralement synthétisés en présence du 15-éther-couronne-5. 


\section{INTRODUCTION}

Zeolites are well-defined microporous aluminosilicate materials obtained by the polymeric combination of $\mathrm{TO}_{4}$ tetrahedra. Their unique design promotes the creation of multidimensional channels and cavities, responsible for their interesting adsorption and diffusion properties [1-3]. Combined with their intrinsic Brönsted acidity and high thermal stability, zeolites are nowadays widely used in petrochemistry and oil refining processes [4-8]. Particularly, FAU-type zeolites are one of the main components of cracking catalysts at the industrial scale due to their structure, one of the most open among zeolites: its porosity is composed of supercages, with a free diameter of $11.6 \AA$, interconnected through circular 12-MemberRing (MR) apertures with a diameter of $7.4 \AA$ [9].

Conventional Y zeolite (FAU-structure type), with a silicon-to-aluminum molar ratio between 1.5 and 2.5, lacks of thermal and hydrothermal stabilities [10]. Nowadays, high silica ultra-stable Y zeolite, with silicon to aluminum molar ratio generally above 4 , is used for cracking applications, allowing good thermal and hydrothermal stabilities [11, 12]. Mainly, ultra-stable $\mathrm{Y}$ zeolite is produced from dealumination of a conventional $\mathrm{Y}$ zeolite by hydrothermal or chemical treatment [13-15]. Unfortunately, these methods require several post-treatments such as calcination under steam (steaming), acid leaching, filtration, washing and drying: this explains the strong interest of a direct "one step" synthesis of high-silica FAU-type zeolites for industrial applications [10].

High silica FAU-type zeolite, with a silicon to aluminum molar ratio between 3 and 5, can be synthesized directly by using specific Structure-Directing Agents (SDA) in a synthesis hydrogel. Thus, Guth et al. reported the crystallization of a high silica FAU-type zeolite commonly named EMC-1 (Elf Mulhouse Chemistry One) by using the 15 -crown-5 ether as SDA [16-18]. The catalytic performances of FAU-type zeolite have been widely studied.

In order to reduce the cost of EMC-1 zeolite, attempts to search for less expensive SDA to direct the formation of high-silica FAU-type zeolites were conducted, but did not afford pure phase. This might arise from a low fit between the SDA and the zeolite structure.

Molecular modeling is an emerging technique in the field of zeolite synthesis [19, 20]. This method is based on mechanical and molecular dynamics techniques, along with Monte-Carlo methods. Particularly, a steric approach was applied to the design of SDA which directs the synthesis of specific frameworks such as ZSM-48 (*MRE), NU-87 (NES), DAF-4 (LEV), DAF-5 (CHA) and $\mathrm{AlPO}_{4}-21$ (AWO) zeolites [21-25].
Herein, using a similar steric approach new di(azacrown ether)-based templates were designed to favor the formation of EMC-1 zeolite. Following a High Throughput Experiment (HTE) design, the synthesis gel composition was optimized to obtain well-crystallized EMC-1 zeolite. The obtained products were fully characterized.

\section{EXPERIMENTAL}

\subsection{Molecular Modeling}

Templates geometry optimization was performed in purely siliceous FAU frameworks using Materials Studio (MS) 5.5 software following a similar steric approach described elsewhere [21, 24]. The energy minimized locations of SDA within theoritical purely siliceous FAU-type structure were obtained by molecular modeling. Energy minimization was performed using Monte-Carlo simulated annealing runtines in the program Discover (implemented in MS Modeling 5.5 by Accelerys Inc.). van der Waals interactions were calculated using the universal forcefield [26]. In this work, the "host-guest" interaction energy (bonding energy) is defined as the difference between the total energy of a system where a template is occluded inside a zeolite framework, and the sum of energies of the template in the vacuum and the zeolite in vacuum:

$$
\begin{aligned}
E_{\text {Host Guest }}= & E_{\text {Zeolite with template occluded }}-\left(E_{\text {template }}\right. \\
& \left.+E_{\text {Zeolite without template }}\right)
\end{aligned}
$$

The deformation energy is defined as the difference between the energy of a template sterically constricted inside a zeolite framework, and the energy of the template in vacuum.

\subsection{Preparation of Di(Azacrown Ether) Templates (ACn-m)}

During this study two templates (AC5-4, AC5-5), designed by molecular modeling, have been synthesized in order to study the spacer length between the macrocycles upon zeolite EMC-1 formation. A schematic representation of those templates is given in Figure 1. They were synthesized in two steps: the first one consists in a diacylation of the aza-crown ether by a diacyl chloride, followed by the reduction of the diamide with lithium aluminum hydride $\left(\mathrm{LiAlH}_{4}\right)$. The experimental conditions of all these syntheses being similar, only the preparation of AC5-4 $\left(M_{w}=492 \mathrm{~g} / \mathrm{mol}\right)$, molecular formula $\mathrm{C}_{10} \mathrm{H}_{20} \mathrm{O}_{4} \mathrm{~N}-\mathrm{C}_{4} \mathrm{H}_{8}-\mathrm{NO}_{4} \mathrm{H}_{20} \mathrm{C}_{10}$ ), will be detailed thereafter. 


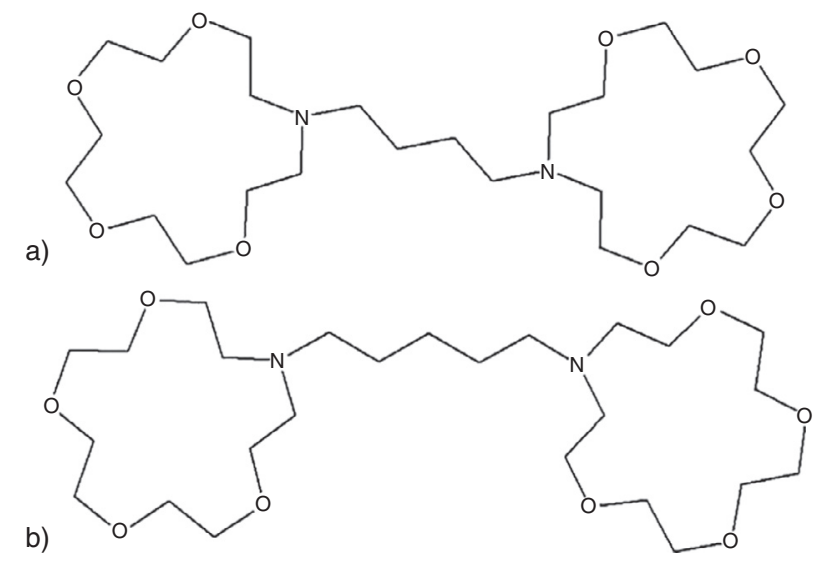

Figure 1

Schematic representation of the different di(azacrown ether) templates used: a) AC5-4 and b) AC5-5.

\subsubsection{Synthesis of AC5-4 Compound}

In a typical synthesis, $4.17 \mathrm{mmol}$ (2.5 eq) of 1-aza-15crown-5 ether (molecular formula $\mathrm{C}_{10} \mathrm{H}_{21} \mathrm{NO}_{4}$, Alfa Aesar) and $6.72 \mathrm{mmol}$ of triethylamine (Alfa Aesar) were dissolved in $11 \mathrm{~mL}$ of freshly distilled dichloromethane (Alfa Aesar). The mixture is first maintained at $0^{\circ} \mathrm{C}$ in an ice bath during dropwise addition of $0.187 \mathrm{~mL}$ (1.69 mmol, $1 \mathrm{eq}$ ) of succinyl chloride (Alfa Aesar), and then stirred at room temperature for 15 hours. The solvent is removed under reduced pressure and the residue is mixed in $15 \mathrm{~mL}$ of ethyl acetate ( VWR Intl) and then filtered. The filtrate, containing the desired diamide and the residual 1-aza-15-crown-5 ether, is purified by column chromatography on silicagel (acetone/triethylamine elutent, $95: 5 \mathrm{v} / \mathrm{v})$. Then $1.4 \mathrm{mmol}(1 \mathrm{eq})$ of the desired diamide and $2.8 \mathrm{mmol}(2 \mathrm{eq})$ of $\mathrm{LiAlH}_{4}(\mathrm{Alfa}$ Aesar) were dissolved in $12.6 \mathrm{~mL}$ of freshly distilled THF (Alfa Aesar) and refluxed for 14 hours. The mixture is treated first with $0.5 \mathrm{~g}$ of $\mathrm{Na}_{2} \mathrm{SO}_{4} \cdot 10 \mathrm{H}_{2} \mathrm{O}$ and then with $1.6 \mathrm{~mL}$ of $\mathrm{NaOH} 1 \mathrm{M}$. The crude residue was washed three times with $30 \mathrm{~mL}$ of ethyl acetate. The crude was then dried with $\mathrm{MgSO}_{4}$ and concentrated under reduced pressure. The final product was identified by ${ }^{1} \mathrm{H}$ and ${ }^{13} \mathrm{C} \mathrm{NMR}$, which were taken from $\mathrm{CDCl}_{3}$ at $22^{\circ} \mathrm{C}$ using a Bruker Instrument. For each chemical shift the number of protons for ${ }^{1} \mathrm{H}$ NMR and Carbon atoms for ${ }^{13} \mathrm{C}$ NMR and their positions (underlined) were assigned.

${ }^{1} \mathrm{H}$ NMR ( $\left.\delta\right):(400 \mathrm{MHz}): 1.38\left(4 \mathrm{H}, \mathrm{NCH}_{2}-\mathrm{CH}_{2}\right.$ in the linear chain); $2.46\left(4 \mathrm{H}, \mathrm{NCH}_{2}\right.$ in the linear chain); 2.72 $\left(8 \mathrm{H}, \mathrm{NCH}_{2}\right.$ in the azacrown ether); $3.61\left(32 \mathrm{H}, \mathrm{OCH}_{2}\right.$ in the azacrown ether).

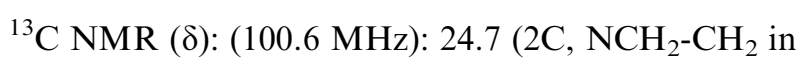
the linear chain); $54.3\left(4 \mathrm{C}, \mathrm{NCH}_{2}\right.$ in the azacrown ether); 56.5 (2C, $\mathrm{NCH}_{2}$ in the linear chain); 69.6, 69.8, 70.1, 70.6 $\left(16 \mathrm{C}, \mathrm{OCH}_{2}\right.$ in the azacrown ether).

\subsubsection{Synthesis of AC5-5 Compound}

AC5-5 $\left(M_{w}=506 \mathrm{~g} / \mathrm{mol}\right.$, molecular formula $\mathrm{C}_{10} \mathrm{H}_{20} \mathrm{O}_{4} \mathrm{~N}-\mathrm{C}_{5} \mathrm{H}_{10}-\mathrm{NO}_{4} \mathrm{H}_{20} \mathrm{C}_{10}$ ), was synthesized following the same procedure using glutaryl chloride (Alfa Aesar) instead of succinyl chloride. The product was then identified by ${ }^{1} \mathrm{H}$ and ${ }^{13} \mathrm{C} \mathrm{NMR}$, which were taken from $\mathrm{CDCl}_{3}$ at $22^{\circ} \mathrm{C}$ using a Bruker Instrument. For each chemical shift the number of protons for ${ }^{1} \mathrm{H}$ NMR and Carbon atoms for ${ }^{13} \mathrm{C}$ NMR and their positions (underlined) were assigned.

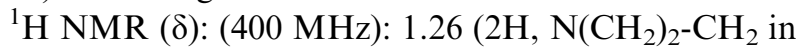
the linear chain); $1.46\left(4 \mathrm{H}, \mathrm{NCH}_{2}-\mathrm{CH}_{2}\right.$ in the linear chain); $2.49\left(4 \mathrm{H}, \mathrm{NCH}_{2}\right.$ in the linear chain); $2.74(8 \mathrm{H}$, $\mathrm{NCH}_{2}$ in the azacrown ether); $3.65\left(32 \mathrm{H}, \mathrm{OCH}_{2}\right.$ in the azacrown ether).

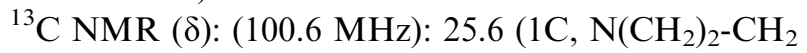
in the linear chain); $27.5\left(2 \mathrm{C}, \mathrm{NCH}_{2}-\mathrm{CH}_{2}\right.$ in the linear chain); $54.8\left(4 \mathrm{C}, \mathrm{NCH}_{2}\right.$ in the azacrown ether); 57.2 (2C, $\mathrm{NCH}_{2}$ in the linear chain); 70.2, 70.4, 70.7, 71.3 (16, $\mathrm{OCH}_{2}$ in the azacrown ether).

\subsection{Synthesis of EMC-1 Zeolite}

The 15-crown-5 (C5) and 1-aza-15-crown-5 (AC5) were used as received from Alfa Aesar. A HTE design was applied to the study, aiming to afford pure FAU-type zeolites by varying $\mathrm{Na}_{2} \mathrm{O}$ and $\mathrm{H}_{2} \mathrm{O}$ molar contents in initial gel compositions. The gel preparations and hydrothermal syntheses were performed using a Tecan Freedom EVO liquid handling robot and a Top Industry high-throughput heated and stirred multi-autoclave unit (100 Monel autoclaves, $5 \mathrm{~mL}$ ), respectively. First, an appropriate amount of template was homogenized in deionized water. Sodium hydroxide (Prolabo, 99\%), then sodium aluminate (Carlo Erba, 56\% $\mathrm{Al}_{2} \mathrm{O}_{3}, 37 \%$ $\mathrm{Na}_{2} \mathrm{O}$ ) were mixed under magnetic stirring until the solution became clear. Finally, Ludox AS-40 colloidal silica (Aldrich, $40 \%$ in water) was added dropwise, so that the molar gel composition for template-mediated FAU syntheses were $10 \mathrm{SiO}_{2}: \mathrm{Al}_{2} \mathrm{O}_{3}: x \mathrm{Na}_{2} \mathrm{O}: y \mathrm{H}_{2} \mathrm{O}: z$ template; with $x=2.1,2.4$ or $2.7, y=100,140$ or 180 and $z=0.6$ (di(azacrown ether) template, noted AC5- $m$ with $m=4$ or 5 and corresponding to the number of carbon atoms between two macrocycles) or 1 (crown ether template, noted $\mathrm{C} 5$, or azacrown ether template, noted AC5). The gel was stirred at $200 \mathrm{rpm}$ during 24 hours, prior to be heated at $110^{\circ} \mathrm{C}$ for 15 days in static 
conditions. After synthesis, the product was filtrated, washed with de-ionized water and dried overnight at $100^{\circ} \mathrm{C}$. The templates were finally removed by calcination in a muffle furnace at $550^{\circ} \mathrm{C}$ during 8 hours in air (ramp at $0.5^{\circ} \mathrm{C} / \mathrm{min}$ ).

\subsection{Characterization}

Liquid ${ }^{1} \mathrm{H}$ NMR $(400 \mathrm{MHz})$ and ${ }^{13} \mathrm{C}(100.6 \mathrm{MHz})$ spectra were recorded with a Bruker Advance 400 spectrometer, in $\mathrm{CDCl}_{3}$ with $\mathrm{Me}_{4} \mathrm{Si}$ as internal standard. Powder $\mathrm{X}$-ray diffraction patterns were collected on a Bruker D4 Endeavor diffractometer equiped with $\mathrm{CuK}_{\alpha 1}$ monochromatic radiation source $(40 \mathrm{kV}, 40 \mathrm{~mA})$. Diffraction patterns in the $2-40^{\circ}$ region were recorded with a $0.02^{\circ}$ step size (step time $=1 \mathrm{~s}$ ). After background subtraction, peak areas in the $19-32^{\circ} 2 \theta$ range $(h k l)=440$, 533, 642 and 555 were used to determine the crystallization rate of the as-synthesized powder, by comparison to the peak areas of the most crystalline EMC-1 sample prepared in this work in the presence of C5. The accuracy is $\pm 5 \%$. Scanning Electron Microscopy (SEM) was performed using a Jeol JSM-6340F, under an acceleration voltage of $1 \mathrm{kV}$. Samples were prepared by depositing a drop of solution containing the sample dispersed in ethanol on an aluminum mounting. Statistical distributions of crystal size were carried on populations of 100 crystals. ThermoGravimetric Analysis (TGA), Differential Thermal Analysis (DTA) were carried out using a TA Instrument SDT 2960 thermoanalyzer between the room temperature and $800^{\circ} \mathrm{C}$, at a heating rate of $5^{\circ} \mathrm{C} /$ min. Reconstituted air $\left(80 \% \mathrm{~N}_{2}\right.$ and $\left.20 \% \mathrm{O}_{2}\right)$ with a flow rate of $1 \mathrm{~L} / \mathrm{h}$ was used during measurement. Nitrogen sorption measurements were performed at $-196^{\circ} \mathrm{C}$ on a Micromeretics ASAP 2010 apparatus. Samples were degassed under primary vacuum at $350^{\circ} \mathrm{C}$ during 10 hours prior analysis. Surface area was calculated according to the BET method [27]. Micropore volume and external crystal surface were determined by using the $t$-plot method [28].

\section{RESULTS AND DISCUSSION}

\subsection{Rational Design of Di(Azacrown Ether) Templates by Molecular Modeling}

It has been shown in previous works that potential new templates for a specified zeolite framework should at least have similar "host-guest" interaction energies to the usual structure-directing agent of the framework, as a lack of "host-guest" interactions might hinder the inclusion of the template or direct the formation of other frameworks [21]. These potential templates should also

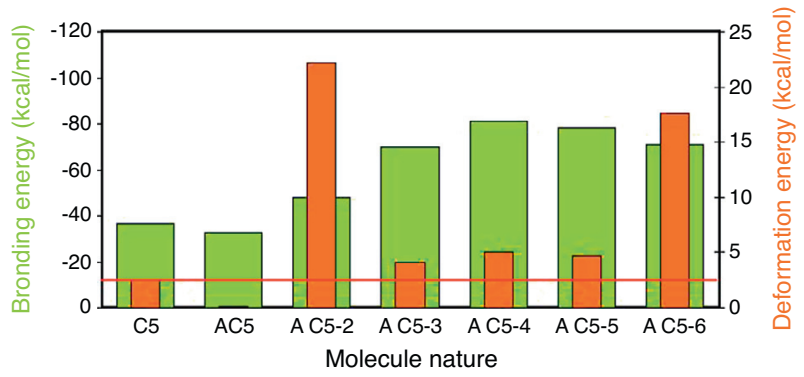

Figure 2

Geometry optimization of several AC5- $m$, with $m=2$ to 6 , compared to their crown ether and azacrown ether analogues. The bonding energy is represented in green, and the deformation energy, in orange.

have the lowest possible deformation energy, meaning that their geometry closely fits to the inner porosity [24]. Regarding this, Figure 2 presents the geometry optimization results of several di(azacrown ether) molecules (AC5- $m$ ) in the FAU framework, compared to the conventional structure-directing agent of EMC-1 zeolite, the 15-crown-5 ether (C5), and the 1-aza-15-crown-5 ether (AC5). As expected, the "host-guest" interaction energy is favorable for all the evaluated AC5- $m$, due to the presence of hydrocarbon spacers linking two structure-directing functions. This, in turn, increases hydrogen bonds between the template and the framework. Deformation energies of the AC5- $m$ templates with spacers composed by three to five carbons are comparable and below $5 \mathrm{kcal} / \mathrm{mol}$, which is close to the C 5 deformation energy, making them an optimal fit for FAU framework. Below and beyond three to five carbons, the deformation energy is clearly unfavorable, meaning that templates can hardly accommodate or fit into the framework. From molecular modeling, it appears that an optimal fit is obtained when a four-carbons spacer length links two structure-directing functions, noted AC5-4, even if it's deformation energy is higher than their crown ether and azacrown ether counterpart. A second AC5-m, with a spacer composed by five carbons, noted AC5-5, gives also similar results and will also be used for zeolite synthesis to evaluate the impact of the spacer length on the crystallinity of the material.

\subsection{Effect of the Synthesis Gel Composition}

Preliminary experiments showed that a variation of the $\mathrm{SiO}_{2} / \mathrm{Al}_{2} \mathrm{O}_{3}$ molar ratio in the presence of $\mathrm{C} 5$ promotes the crystallization of $\mathrm{P}$ (Gismondine type (GIS-type) structure) and A Linde Type A (LTA) zeolites. 


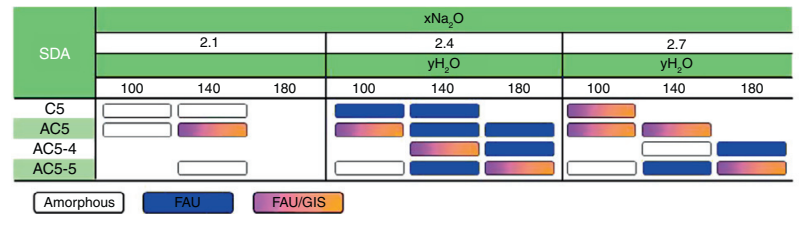

Figure 3

Phase diagram of the materials synthesized at $110^{\circ} \mathrm{C}$ during 15 days and at the following gel molar composition: $10 \quad \mathrm{SiO}_{2}: 1 \quad \mathrm{Al}_{2} \mathrm{O}_{3}: x \quad \mathrm{Na}_{2} \mathrm{O}: y \quad \mathrm{H}_{2} \mathrm{O}: z$ template with $z=0.6$ (di(azacrown ether) template $=$ AC5- $m ; m=4$ or 5 ) or 1 (mono(azacrown ether/crown ether) template $=$ AC5 and C5). Only the main phases are reported. In the presence of AC5-5 template, no pure material is obtained: in all cases, besides the crystalline phase amorphous material is detected.

Thus, the $\mathrm{SiO}_{2} / \mathrm{Al}_{2} \mathrm{O}_{3}$ molar ratio should be kept constant at the typical value of 10 during this study to avoid the formation of these undesired phases. The molar content of template was also modified until no further increase of the sample crystallinity was observed.

Results of the applied experimental design are summarized in Figure 3. At high $\mathrm{Na}_{2} \mathrm{O}$ molar content, co-crystallization of $\mathrm{P}$ zeolite (GIS) generally occurs. At the opposite, no crystallized material is detected after 15 days at low $\mathrm{Na}_{2} \mathrm{O}$ molar content: lowering the concentration of mineralizing agent $\left(\mathrm{OH}^{-}\right)$usually induces a lower sursaturation, resulting in a less reactive hydrogel. As expected, C5 shows the most specific structuredirecting effect amongst all the tested templates. It leads to the formation of well-crystallized EMC-1 zeolite, from a wide range of gel compositions. This is in accordance with previous works [16-18].

The use of AC5 allows to obtain a FAU-type zeolite from several gel compositions, but $\mathrm{P}$ zeolite also co-crystallizes in a wide range of gel composition, which might be interpreted as a lower structure-directing effect of AC5 compared to C5. Previous studies concluded that the structure-directing agent of EMC-1 zeolite was not the crown ethers alone but rather the association of crown ethers with sodium cations as a complex with a planar conformation [29-31]. The AC5/sodium cation complexe is expected to adopt a curved conformation [32]. Then, the lack of structure selectivity observed might arise from the presence of nitrogen elements in the templates.

Observations were sensibly identical when using di(azacrown ethers), except that the proportion of amorphous material obtained is more important at low $\mathrm{Na}_{2} \mathrm{O}$ molar content. Moreover, as it will be seen below (thermal analysis and $\mathrm{N}_{2}$ adsorption measurements) for the

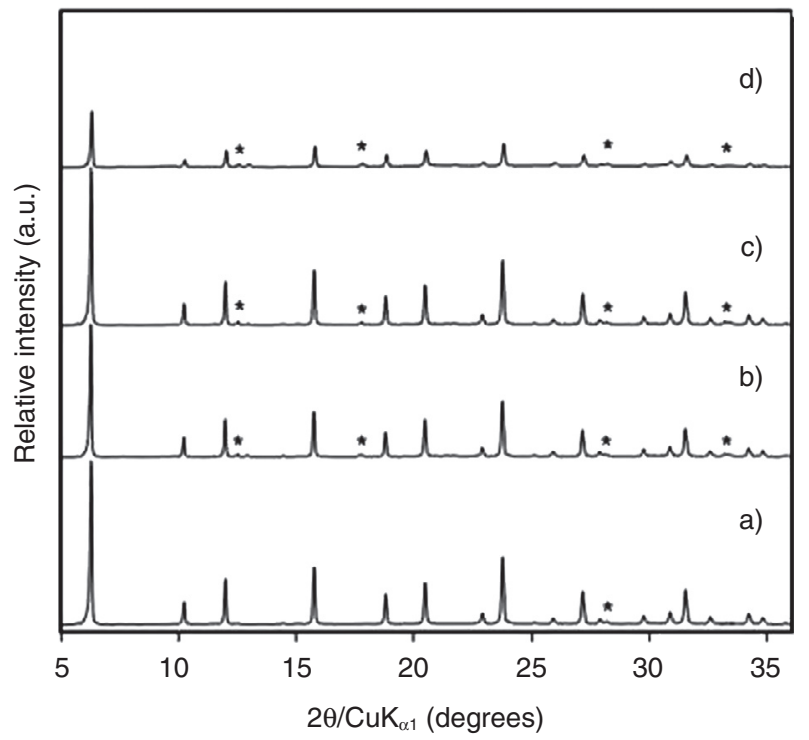

Figure 4

XRD patterns of the as-synthesized FAU-type zeolites selected for further characterizations, synthesized in the presence of: a) $\mathrm{C} 5(x=2.4, y=140, z=1)$; b) $\mathrm{AC}_{5}$ $(x=2.4, y=140, z=1)$; c) AC5-4 $(x=2.4, y=180$, $z=0.6)$ and d) AC5-5 $(x=2.7, y=140, z=0.6)$. Traces of GIS-type zeolites are indicated by an asterisk.

AC5-5 sample, amorphous material is always present besides the crystalline phase. Therefore, for this sample it is better to talk of crystallization rate rather than relative crystallinity.

The X-ray diffraction patterns of FAU-type zeolites synthesized in the presence of the different templates and selected for further characterizations are presented, in Figure 4. Every template possesses a relatively good structure-directing effect, leading specifically to FAUtype zeolite within close synthesis gel compositions. Particularly, the relative crystallinity of AC5 (85\%) match to the crown ethers C5 (100\%, reference). The crystallization rate of the sample synthesized in the presence of AC5-5, reaching 60\% (Fig. 4d), is clearly lower than the crystallinity of the sample synthesized with AC5-4, up to $95 \%$ (Fig. 4c), indicating that the 4-carbons spacer fits better to the EMC-1 structure than a 5-carbons spacer as initially observed by molecular modeling.

Templates integrity was verified by ${ }^{1} \mathrm{H}$ liquid NMR, after dissolution of the inorganic framework in a HF solution, by comparaison of the NMR spectrum with the spectrum of the same template before synthesis. These crystallized materials were further characterized. 


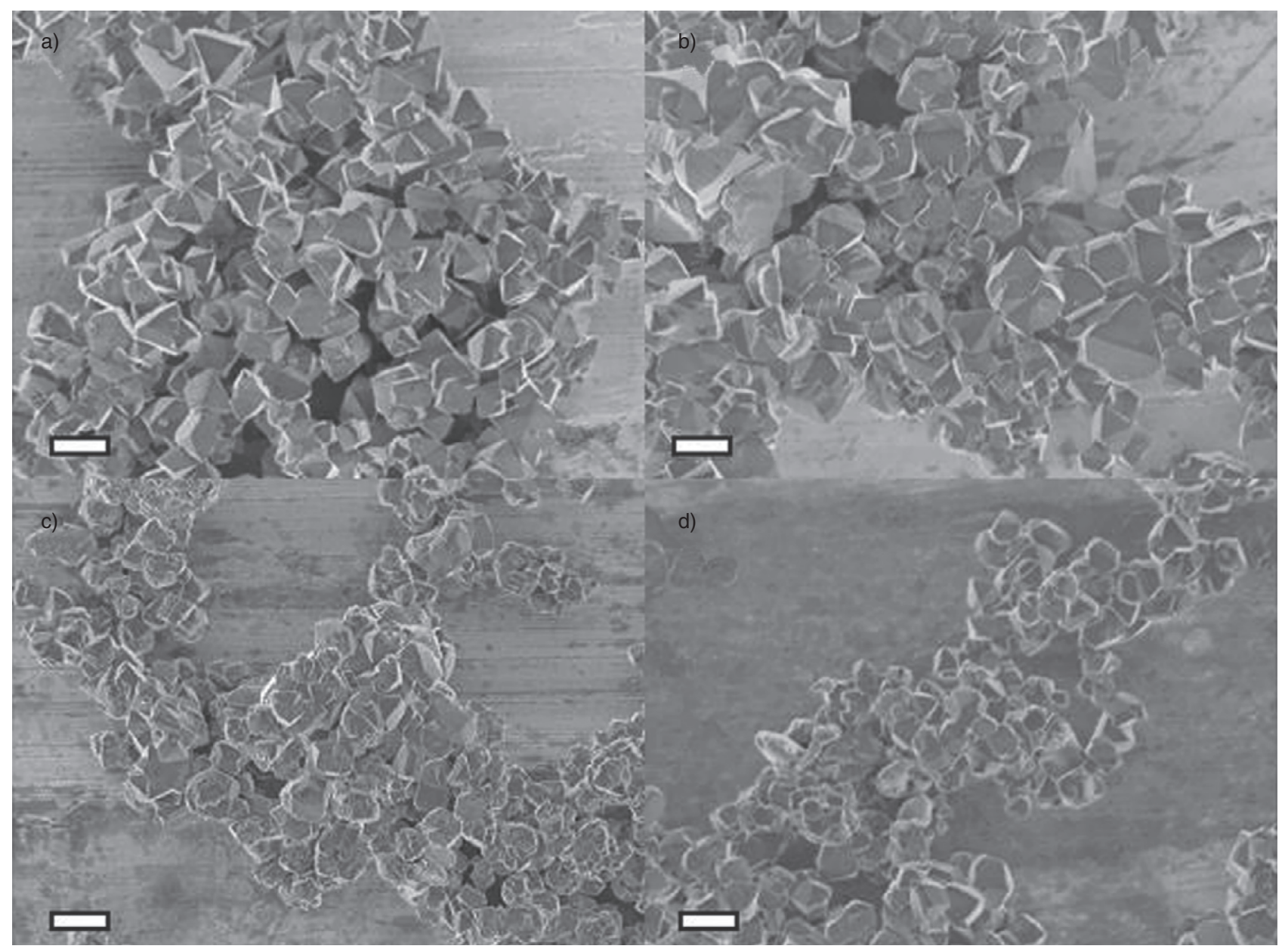

Figure 5

SEM images of FAU-type zeolites synthesized in the presence of: a) C5 ( $x=2.4, y=1, z=140)$; b) AC5 $(x=2.4, y=1, z=140)$; c) AC5-4 $(x=2.4, y=0.6, z=180)$ and d) AC5-5 $(x=2.7, y=0.6, z=140)$. The scale bars represent $2 \mu \mathrm{m}$.

\subsection{Characterization of the Crystallized Samples}

Figure 5 presents SEM images of the as-synthesized samples prepared with C5, AC5 and AC5- $m$ as structuredirecting agents. A typical octahedral shape, attributed to FAU-type crystals, is observed for each one. One may notice that in the presence of AC5-m, the synthesized crystals were sensibly smaller. This observation was further verified by studying the statistical distributions of crystal sizes, summarized in Table 1. Indeed, in comparison with the crystals synthesized in the presence of C5 (Fig. 5a) a 10\% size reduction is observed when using AC5-4, with a slightly more uniform distribution (Fig. 5c), and reaches the $32 \%$ when using AC5-5 (Fig. 5d). However, the crystallization rate of the latter $(60 \%)$ indicates that this size reduction could be related to an incomplete growth.
TABLE 1

Size distribution range and average size of a population of 100 crystals, measured from SEM images analysis

\begin{tabular}{c|c}
\hline Template & $\begin{array}{c}\text { Diameter distribution range } \\
(\text { average diameter })(\mu \mathrm{m})\end{array}$ \\
\hline C5 & $0.7-1.9(1.30)$ \\
\hline AC5 & $0.7-2.3(1.55)$ \\
\hline AC5-4 & $0.7-1.7(1.16)$ \\
\hline AC5-5 & $0.4-1.4(0.88)$ \\
\hline
\end{tabular}

Thermal analyses of FAU-type materials are presented in Figure 6 . Below $200^{\circ} \mathrm{C}$, a first weight loss corresponding to water molecules desorption and characterized by an endothermic peak on the DTA curve (not shown) is observed. Between 200 and $650^{\circ} \mathrm{C}$, several 


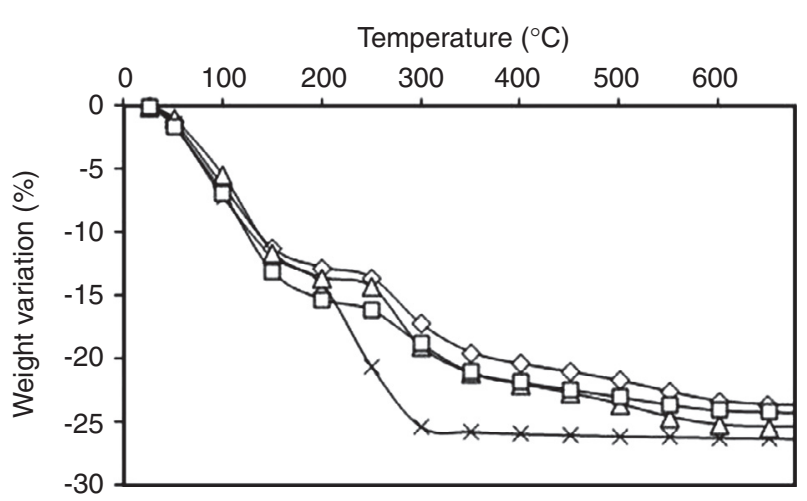

Figure 6

Thermal analyses of as-synthesized FAU-type zeolites obtained in the presence of C5 ( $x=2.4, y=1, z=140)$ (cross), AC5 $(x=2.4, y=1, z=140)$ (rhombus), AC5-4 $(x=2.4, y=0.6, z=180)$ (triangle) and AC5-5 $(x=2.7, y=0.6, z=140)$ (square).

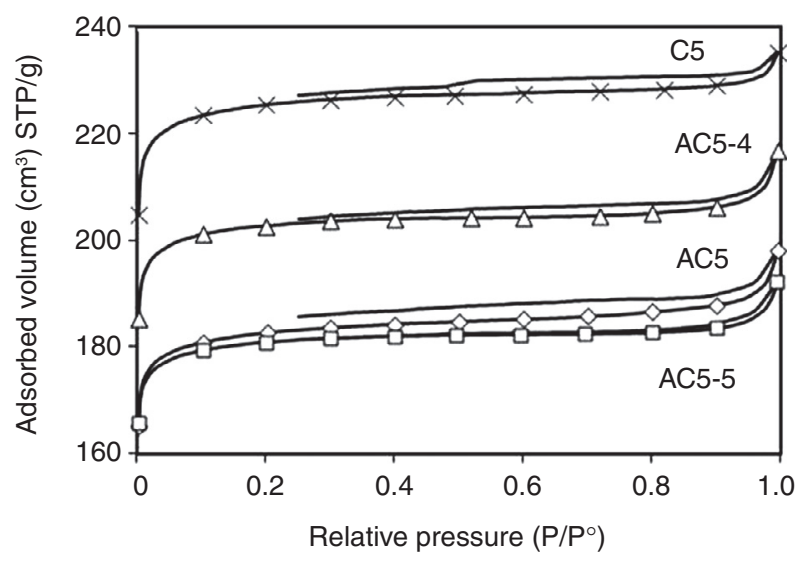

Figure 7

Nitrogen adsorption/desorption isotherms at $-196^{\circ} \mathrm{C}$ of the calcined FAU-type zeolites.

exothermic peaks indicate that the structure-directing agents occluded into the zeolite framework are main contributors of the weight loss, along with some remaining water molecules. After determination of the approximate molecular weight of a FAU-type zeolite unit cell $\left(M_{w}=12328 \mathrm{~g} / \mathrm{mol}, \mathrm{Si} / \mathrm{Al}=4.3\right)$ and that 8 crown ether/sodium cation complexes are present per unit cell of a completely crystallized sample [18], one can evaluate the samples purity by calculating the number of crown ethers in one unit cell. As expected, 8 complexes are present per unit cell for the samples structured by C5 $(12 \%$ $\mathrm{w} / \mathrm{w})$ and $\operatorname{AC} 5(11 \% \mathrm{w} / \mathrm{w})$. AC5- $m$ templates contain 2 structure-directing functions per molecule: we expect to find only 4 complexes per unit cell. The weight loss
TABLE 2

Textural properties of the calcined zeolites, measured by $\mathrm{N}_{2}$ sorption

\begin{tabular}{c|c|c|c}
\hline Template & $\begin{array}{c}S_{B E T} \\
\left(\mathrm{~m}^{2} / \mathrm{g}\right)\end{array}$ & $\begin{array}{c}S_{\text {extern }} \\
\left(\mathrm{m}^{2} / \mathrm{g}\right)\end{array}$ & $\begin{array}{c}V_{\text {micro }} \\
\left(\mathrm{cm}^{3} / \mathrm{g}\right)\end{array}$ \\
\hline C5 & 817 & 43 & 0.33 \\
\hline AC5 & 660 & 40 & 0.27 \\
\hline AC5-4 & 737 & 32 & 0.30 \\
\hline AC5-5 & 747 & 30 & 0.20 \\
\hline
\end{tabular}

determined for AC5-4 corresponds to this value $(12 \% \mathrm{w} /$ $\mathrm{w})$, meaning that the sample is close to a full crystallization. However, for AC5-5, the weight loss is lower than expected $(9 \% \mathrm{w} / \mathrm{w})$, implying that the crystallization rate is only about $65 \%$ and that this material still contains amorphous hydrogel. This is in agreement with XRD observations (i.e. 60\%, see Sect. 2.2 and Fig. 4d).

Figure 7 presents the nitrogen adsorption-desorption isotherms of the different materials. A typical type I adsorption isotherm is obtained in each case, indicating that the materials were microporous. Additional H4 hysteresis can be observed on most of the isotherms. This generally occurs in the presence of narrow slit-like mesopores, responsible for capillary condensation.

Table 2 resumes the textural properties of the chosen crystallized materials. A very similar microporosity was observed in each case, apart for AC5-5 confirming thus the presence of amorphous material in this sample.

\section{CONCLUSION}

Molecular modeling was used to design new templates favorable to the synthesis of EMC-1 zeolite. An optimal fit was obtained when a four-carbons spacer links two azacrown ether molecules. A high throughput experiment design was applied to optimize the synthesis gel composition in the presence of the mono or di(azacrown ether) templates. EMC-1 zeolite was obtained in restricted gel composition domains. This work paves the way for the further design of complex templates with the ability to finely tailor both structural and textural properties of FAU-type zeolites.

\section{REFERENCES}

1 Davis M.E. (2002) Ordere porous materials for emerging applications, Nature 417, 813-821.

2 Lauridant N., Daou T.J., Arnold G., Soulard M., Nouali H., Patarin J., Faye D. (2012) Key steps influencing the formation of ZSM-5 films on aluminum substrates, Micro. Meso. Mater. 152, 1-8. 
3 Corma A. (2003) State of the art and future challenges of zeolites as catalysts, J. Catal. 216, 298-312.

4 Bartholomew C.H., Farrauto R.J. (2006) Fundamentals of Industrial Catalytic Processes, 2nd ed., John Wiley and Sons, New Jersey, pp. 60-78.

5 Corma A. (1995) Inorganic solid acids and their use in acidcatalyzed hydrocarbon reactions, Chem. Rev. 95, 559-614.

6 Čejka J., Centi G., Perez-Pariente J., Roth W.J. (2012) Zeolite-based materials for novel catalytic applications: Opportunities, perspectives and open problems, Catal. Today 179, 2-15.

7 Liu Z., Wang Y., Xie Z. (2012) Thoughts on the Future Development of Zeolitic Catalysts from an Industrial Point of View, Chin. J. Catal. 33, 22-38.

8 Thomas F., Degnan Jr. (2000) Applications of zeolites in petroleum refining, Top. Catal. 13, 349-356.

9 Bergerhoff G., Baur W.H., Nowacki W. (1958) Die kristallstrukturen des faujasits, N. Jb. Miner. Mh. 193-200.

10 Waltermann G.M., Magee J.S., Griffith S.D. (1993) Commercial preparation and characterization of FCC catalysts, Stud. Surf. Sci. Catal. 76, 105-144.

11 Vermeiren W., Gilson J.-P. (2009) Impact of zeolites on the petroleum and petrochemical industry, Top. Catal. 52, 1131-1161.

12 van Donk S., Janssen A.H., Bitter J.H., de Jong K.P. (2003) Generation, Characterization, and Impact of Mesopores in Zeolite Catalysts, Catal. Rev. - Sci. Eng. 45, 297-319.

13 Bedard R.L. (2002) Zeolites in Industrial Separation and Catalysis, Wiley-VCH, Weinheim, pp. 72-73.

14 Tatsumi T. (2010) Handbook of Porous Solids, Wiley-VCH, Weinheim, pp. 913-920.

15 Kerr G.T. (1967) Intracrystalline rearrangement of constitutive water in hydrogen zeolite Y, J. Phys. Chem. 71, 4155-4156.

16 Delprato F., Delmotte L., Guth J.-L., Huve L. (1990) Synthesis 1 of new silica-rich cubic and hexagonal faujasites using crown-etherbased supramolecules as templates, Zeolites 10, 546-552.

17 Delprato F., Guth J.-L., Anglerot D., Zivkov C. (1988) Method for the synthesis ofzeolites belonging to the structural family of faujasite, products obtained and their use in adsorption and catalysis, FR Patent 8.813.269.

18 Dougnier F., Patarin J., Guth J.-L., Anglerot D. (1992) Synthesis, characterization, and catalytic properties of silica-rich faujasite-type zeolite (FAU) and its hexagonal analog (EMT) prepared by using crown-ethers as templates, Zeolites 12, 160-166.

19 Moini A., Schmitt K.D., Valyocsik E.W., Polomski R.F. (1994) The role of diquaternary cations as directing agents in zeolite synthesis, Zeolites 14, 504-511.
20 Lewis D.W., Freeman C.M., Catlow C.R.A. (1995) Predicting the Templating Ability of Organic Additives for the Synthesis of Microporous Materials, J. Phys. Chem. 99, 11194-11202.

21 Schmitt K.D., Kennedy G.J. (1994) Toward the rational design of zeolite synthesis: The synthesis of zeolite ZSM18, Zeolites 14, 635-642.

22 Casci J.L., Cox P.A., Henney R.P.G., Maberly S., Shannon M.D. (2004) Template design for high-silica zeotypes: A case study of zeolite nes synthesis using a designed template, Stud. Surf. Sci. Catal. 154, 110-117.

23 Thomas J.M., Lewis D.W. (1996) Towards rational design of solid acid catalysts, Z. Phys. Chem. 197, 37-48.

24 Lewis D.W., Sankar G., Wyles J.K., Thomas J.M., Catlow C.R.A., Willock D.J. (2003) Synthesis of a Small-Pore Microporous Material Using a Computationally Designed Template, Angew. Chem. Int. Ed. 36, 2675-2677.

25 Song Y., Li J., Yu J., Wang K., Xu R. (2005) Towards Rational Synthesis of Microporous Aluminophosphate $\mathrm{AlPO}_{4}-21$ by Hydrothermal Combinatorial Approach, Top. Catal. 35, 3-8.

26 Rappe K., Casewit C.J., Colwell K.S., Goddard W.A., Skiff W.M. (1992) UFF, a full periodic table force field for molecular mechanics and molecular dynamics simulations, J. Am. Chem. Soc. 114, 10024-10035.

27 Brunauer S., Emett P.H., Teller E. (1938) Adsorption of Gases in Multimolecular Layers, J. Am. Chem. Soc. 60, 309-319.

28 Lippens B.C., de Boer J.H. (1965) Studies on pore systems in catalysts: V. The $t$ method, J. Catal. 4, 319-323.

29 Feijen E.J.P., De Vadder K., Bosschaerts M.H., Lievens J. L., Martens J.A., Grobet P.J., Jacobs P.A. (1994) Role of 18-crown-6 and 15-crown-5 ethers in the crystallization of polytype faujasite zeolites, J. Am. Chem. Soc. 116, 29502957.

30 Baerlocher C., McCusker L.B., Chiappetta R. (1994) Location of the 18-crown-6 template in EMC-2 (EMT) Rietveld refinement of the calcined and as-synthesized forms, Micro. Mater. 2, 269-280.

31 Burkett S.L., Davis M.E. (1993) Structure-directing effects in the crown ether-mediated syntheses of FAU and EMT zeolites, Micro. Mater. 1, 265-282.

32 Freidzon A.Y., Vladimirova K.G., Bagatur'yants A.A., Gromov S.P., Alfimov M.V. (2007) Theoretical study of complexation of alkali metal ions in the cavity of arylazacrown ethers, J. Mol. Struct. 809, 61-71.

Manuscript accepted in May 2014 Published online in September 2014

Cite this article as: T.J. Daou, J. Dhainaut, A. Chappaz, N. Bats, B. Harbuzaru, H. Chaumeil, A. Defoin, L. Rouleau and J. Patarin (2015). The Use of Original Structure-Directing Agents for the Synthesis of EMC-1 Zeolite, Oil Gas Sci. Technol 70, 3, 447-454. 